\title{
RESILIENCE: PHENOMENOLOGICAL STUDY ON THE CHILD OF PARENTAL DIVORCE AND THE DEATH OF PARENTS
}

\author{
Yuni Kartika \\ Post Graduate Student in Psychology at Universitas Gadjah Mada \\ Yunikartika123@gmail.com
}

\begin{abstract}
Losing both parents due to divorce or death is a traumatic incident that produces a source of stress in life. This will be bad for the person's life since it might create a sense of loneliness, a grave need for affection, and financial problems. Individuals need an ability to overcome problems called resilience. Resilience is a capacity to respond soundly and productively when facing misery or traumatic events. Subjects in this study experienced trauma from parental divorce and death of both parents. When both parents were still alive, the subject never received attention from his father since he had remarried while his mother was forced to work abroad to fulfill their financial needs. The subject was raised by his grandparents with a strong upbringing pattern and lacked the support for achievement. However, the subject managed to grow to be an independent adult and survive the difficult conditions suffered while still managed to be whatever he wants without harming others. The purpose of this study is to investigate the resilience dynamics of a child experiencing parental divorce and death. This research uses phenomenology approach. Subject in this study consisted of one person based on typical case sampling. The typical cases discussed here are divorce and death of both parents. Data is collected using semi-structured interview method and then analysed using thematic analysis.

The result of this study indicates that the subject has developed resilience from adverse events happened to him. The greatest effects experienced by the subject from this traumatic event are the low level of family support, the sense of loneliness, problems with the authoritarian style of rearing he endured while living with the parent's family after parental divorce until both parents died that make it difficult for him to trust others, as well as low self-esteem. But these adverse effects had not made him desperate with his life. The subject's involvement in social activities has succeeded in changing his view toward life more positively and making the subject self-sufficient individual. Factors such as hardiness, locus of control and spirituality are found in the subject and contribute to the subject's ability to survive even without the full support of the family. In essence, the involvement of subjects in social activities is the greatest source and influence from where the subject rebuilt his view of life, to rise above the problem and become a more positive individual.
\end{abstract}

Keywords: Resilience, divorce of parents, death of parents

\section{INTRODUCTION}

Every child expects full affection from both parents, but if the parents are divorced, it will have a negative impact, not only for the parents but also for their children. This can have an impact that affects the child's psychological condition, for example it can turn the child into a quiet kid, lower self-esteem, increase excessive delinquency, worse educational achievement and feeling of lost (M Yusuf, 2014). The impact of parents' divorce also causes problems in the child's emotional development (Estuti, 2013) and loneliness (Altundag \& Bulut, 2014). 
Parents are the ones closest to the child. When a child is confronted with the event of death the parents, it surely will be difficult for the child to accept this as a fact, as in the event of death the children is severed from their relationship with their parents. The death of both parents means the children will lose the figure of parents as a place for them to get affection in full. The absence of a parent due to death is a stressful life change and requires individuals to respond to adjustments (Atwater, 1999).

Childhood is seen as a critical building period in which children need protection because of their physical and psychological vulnerabilities. Children living with mentally ill parents are a risk factor for the emergence of mental illness except for individuals with good resilience (Gladstone, Boydell, \& McKeever, 2006). It takes an ability to adapt after the traumatic events that happened to them. Early traumatic experiences such as divorce or death of the elderly affect the emergence of future depression (Poole, Dobson \& Pusch, 2017), but the ability of resilience to be a protective and preventive factor to prevent depression and feelings neglected in children (Bucur, Bucur \& Runcan, 2013; Schulz et al., 2014). Scientists view resilience as the ability to rise from a traumatic situation or event. Resilience is defined as the ability of a person to face adversity, to achieve a better life (Linley \& Joseph, 2004). On the other hand, resilience is defined as a person's mental qualities that help him to thrive even when faced with a stressful situation (Connor \& Davidson, 2003).

A person who has the ability to resonate well will be able to develop more positively to focus more on the competencies that exist in him (Linley \& Joseph, 2004). According to Reivich \& Schatte (2002), resilience is the capacity to respond soundly and productively when faced with misery or trauma, which is necessary to manage the stresses of everyday life. Seven capabilities of a resilient individual are emotion regulation, impulse control, optimist, problem cause analysis, empathy, self-efficacy, reaching out. The first, emotional regulation is a basic ability to sense what is felt. Child victims of divorce and death of parents with good emotional regulation able to remain calm from the traumanya conditions. Second, impulse control, ndividuals with good resilience will be able to control their own desires, drives, preferences, and pressures from within. Children with divorce victims and deaths of parents who have good impulse controllers can see the things they experienced by thinking first before acting. Third, optimist. Child victims of divorce and death of parents believe that they still have bright hopes in the future. They continue to believe that they can achieve the ideal in life after the traumatic event experienced. Fourth, problem cause analysis. This ability is related to the ability to think broadly about the problems it faces. Child victims of divorce and death of parents have good cognitive analysis in identifying problems so as to deal with life problems more logically and systematically. Fifth, empathy. The ability of empathy is characterized by the individual's ability to read psychological and emotional signs from others. Empathy reflects how well individuals understand the psychological state and emotional needs of others. A person who has a high sense of empathy tends to have positive social relationships. Sixth, self efficacy. Self efficacy is a belief, or expectation of the extent to which individuals estimate their ability to perform certain tasks or actions necessary to achieve desired outcomes (Bandura, 1977). Self efficacy is to trust in your own ability to effectively problem mech. Child victims of divorce and deaths of parents who have good self efficacy are committed to problem solving and never give up on the conditions and circumstances when finding that strategy used in solving a previously unsuccessful problem. Seventh, reaching out. Resilience is an ability that includes an increase in the positive aspects of life. Child victims of divorce and the death of parents who have high resilience will think and deal with problems in his life with a positive (Reivich \& Schatte, 2002).

The ability of resilience becomes important for individuals of all ages to respond to problems that occur in life because it will affect their ability to respond problems that occur in life positively. Resilience becomes the latest paradigm needed to understand the emergence of pathology. Resilience is a positive concept that enhances one's ability to cope with the negative events experienced in his life (Altundag \& Bulut, 2014). Individuals need resilience. The success of this resilience ability can be influenced by autonomy and competence (the ability to adapt to the environment) (Thomas \& Woodside, 2011) for adjustment in the face of traumatic events in a row. Brown (2015) found an effective way to reduce the risk of psychological problems caused by traumatic events experienced by individuals. Brown in his literature study concluded that factors such as locus of control, optimism, and hardiness greatly affect one's ability to resilient. Grotberg (2000) suggests that there are factors that make a person able to do resilience. Factor "I Am" is a power that comes from within oneself. Factor "I Have" is external support. Factor "I can" is the ability of the individual to express feelings and thoughts in communicating with others.

Research will be based on a brief interview conducted on the subject of the study, it is important to note that the subject is a child victim of a parent divorce. The subject said that he was nurtured so harsh by his grandparents that it made him in conflict with them often. Father of the subject did not held much responsibility about the needs of the subject anymore. At the age of 16 years old, the subject lost both parents forever. The subject never felt any support from his family. However, the uniqueness of the subject 
of this study is that the traumatic conditions experienced by him, did not make him grow into an individual who deviates toward negative things, on the contrary, the subject grew into a positive person. This can be seen from the success of the subject in continuing his master's study with scholarships, attending national and international conferences while actively organized on and off campus. The traumatic incident that befalls the subject should have pushed the subject into a slump and have other psychological and social problems. But the reverse is happening on the subject, the subject turned into an achiever, have a good social relationships and did not involved in any promiscuities. Researcher is encouraged to comprehend the psychological dynamics of research subject who had a broken home until both parents died that ultimately make the subject grow into a positive person, and researcher is encouraged to comprehend what are the sources of resilience that helped the subject surviving his life. This study focuses on describing the resilience of children who experienced divorce and/or death of parents. To know this, the researcher will focus on the impacts of divorce and death of the parents experienced by the subject along with understanding the sources of resilience formation on the subject.

\section{METHOD}

\subsection{Subject}

This research uses phenomenology research design. According to Creswell (2015) phenomenology study is a study that seeks to "essence" the meaning of a phenomenon experienced by some individuals. In this study, researchers applied a hermeneutic phenomenology research that sought to interpret the experiences experienced by the research subjects.

The subject in this study is one person using a typical case sampling technique. Typical cases raised are divorce and death of parents. The subject age is 26 years old, male, originally came from Makassar, is a Muslim and live in Yogyakarta. IM is the youngest child among his brothers. IM parents were divorced when he was 5 years old. IM's father's occupation was a mechanic in the mechanical shop and his mother was a housewife. After graduation from Senior High School IM once applied to be a police officer, enlisting to the army recruitment, and also applied to the IPDN (Institute of Domestic Government), Immigration, air force, navy and he also applied to be a student at two universities but all were rejected.

\subsection{Data Collection Method}

The researchers conducted data collection by interview. Researchers conducted face-to-face interviews, where there were several interview guidelines. The interview guidelines are around themes of experience before, during and after divorce and death of parents, protective factor, and success characteristics of resilient.

\subsection{Credibility and Research Ethics}

Credibility is the extent to which a qualitative study can be trusted and accountable and can be used or applied. The credibility of qualitative studies lies in achieving the goal of exploring problems or describing settings, processes, social groups or complex interaction patterns (Poerwandari, 2005). To ensure the credibility of the research, researcher attach all verbatim data from the interview and the informed consent of the participant stating his willingness to corroborate as evidence that the research has been conducted to the subject of the research along with the documentary evidence of subject involvement in social activities. In this research, the researcher provides informed consent in the form of participant's statement that he willingly become a research subject and fully involved to assist the researcher in completing the research data, from a document, interview recording etc.

\section{RESULT}

\subsection{Description of Subject Condition}

Before divorce and death of parents the subject has know that both parents are often in conflict. Divorce occurs when the subject is 5 years old. The Parents divorce was caused by several factors. First, the financial insufficiency compared to for the family needs. Second, the father is incapable as a leader in family, especially to fulfill the responsibility as a father for his children and as a husband for his wife in earning a living. Third, problems caused by inter-parent interferences in regulating the household relationship by both parents of the subject, especially regarding financial problems. After the divorce IM lived with his grandparents. IM also lived with his uncle for about 3 years in Jakarta since 2007-2010, unfortunately because of some urgent cases he had to go to his hometown to continue his study and continue living with his grandparents. His mother went on to work as a female labor (TKW) in Malaysia working as a tailor, since 1997 until her death in 2008. The major reason she had to work as a female labor in Malaysia after the 
divorce was the fact that she herself took care of both children she had and took fully responsibility as both father and mother in the household to fulfill the daily needs, moreover his father rarely visited nor provided them. While his father remarried and did not care about the IM anymore. IM did not know when his father died because of the death of his father he knew when he was an adult and the cause of death was due to illness.

In School, IM often involved in mischievious quarrel with his friends. One time he did not want to continue attending school because he felt that he was let alone by his grandparents and they did not provide a proper nurture for IM to continue education. Luckily IM was not involved in the negative adolescence environment which abuse drugs, promiscuity and alcohol so IM managed to finish his studies. When IM was in the second degree of senior high school his mother died due to traffic accident on the street in Malaysia, and three months later after the accident his father died caused by long-drawn illness. Fortunately, for as long as she worked as a migrant worker in Malaysia IM's mother managed to save some money, so they can lease a plots of land, built home and open a gardening field. It was the source of income to finance IM school until IM successfully complete his undergraduate degree. Both of IM's grandparents worked as a tailor at home, they did not give much him input for his career in the future they just managed few stuffs for IM's life, a few suggestion for life and a few perspective in seeing life. IM claimed to the feeling of sadness due to the death of both parents is not so profound because since childhood IM very rarely met his parents.

After IM's parents divorced and death he stayed with grandparent, then living with his uncle. Because his uncle died too, finally he moved back with grandparent. He confessed that he grew up as an unwilling and stubborn child. This behavior he admitted. This resulted in his grandparents who reacted by also harsh in nurturing IM. The subject confessed that he had no close physical and psychological proximity to both parents so at the time of the death of his parents when the subject was 16 years old, he did not feel significant losses.

After finishing undergraduate IM regularly followed social activities, IM met many people that came from many backgrounds. It was then and there that he realized that he was nothing. Finally, after graduation from college, he chose to work as a teacher. His insights widen, his hard and gruff nature slowly diminished as he met new people until he finally intended to continue his studies to a higher level with a scholarship.

\subsection{Protective Factor}

Traumatic events ranging from divorce to parental deaths in addition to post-incidents IM faced with the ignorance of his grandparents as the closest family members with harsh upbringing as well as being rejected from various workplaces would certainly made IM struggle to survive and form a better future. IM admitted he never felt the affection of his parents, he also felt lonely, and ignored and had no place to share stories. Everything that is desired must be pursued alone because there is no full family support. IM also don't have close friends because of his low self-esteem regarding his family background. IM often cried in his room, feeling regret because he did not have a chance to serve his parents before they died.

The effects of divorce and death of the parents experienced by the subject does not make the subject resigned to his life. The subject fights alone with everything that becomes his target despite many obstacles. Based on the results of the interview, the subject acknowledge that by continuing his studies without relying on the family, engaging in various organizational activities, attending national and international conferences as well as being a speaker in various places he can proof that he has the ability to build his life for a better future. This means that the subject has a good locus of control, especially the internal locus of control (the belief that one can control events in life. This can be found on the subject. The trauma he had experienced enables him to have the ability to think optimistically and always think about the capabilities he possess to be successful, while not thinking about failure and disability that ultimately lead to depression. It was also known, that subject has 3 characteristics of hardiness that is control, commitment, and challenge. Subject are able to control himself by forbidding himself not to engage in adverse activities, demonstrated commitment to the achievement to make the institution that have given him scholarship proud and always face challenges. Like when his parents had died and his immediate family did not give him full support to be successful, the subject fought on his own to fulfill his dreams.

Judging from the factor "I Am", the subject has difficulty to love other people and the subject is also not proud of what he has achieved. Subject found it difficult to open up with others especially with regard to family conditions because everything is considered useless due to the death of the people he loves. Factor "I Have", the financial support prepared by the subject's mother for his success made him obligated to rise up and very determined to realize his dreams as well as the dream of his mother who wants to become a teacher. Subject is also active in the world of organizations inside and outside the campus to fill in the spare time during his study. Subject is involved in an organization that focus on the education in remote schools. 
This factor is what made him resilience (I can) by educating himself independently to solve his own problems and not depend entirely on others. Subject also feels heavily indebted to the institution that has awarded the scholarship to him so he is determined to send other people to school and build an Islamic school. Loneliness due to longing for both parents made him participate in volunteer teaching activities because according to him meeting new people can successfully change his view of life, by showing him how to survive strongly and positively.

Other factors such as spirituality are also influential in building the resilience (Pandya, 2017). The influence of spirituality is seen in the subject. Environmental conditions surrounding the subject such as religious friends and subject residence close to the mosque have an effect on building resistance within subject. Researcher also saw several times that the subject routinely did prayer worship in the mosque. This affects the subject himself and he began to think that his rough nature made him feel as a disobedient and sinful child, therefore the subject seeks to change himself slowly.

\subsection{Characteristic of Resilience}

In the data that has been obtained on the characteristics of resilient individuals from the subject. Regarding the dimension of emotional regulation, subject confessed that he was grumpy, rude and cranky. This is seen in the interview. He said: "I was grumpy, rude and cranky. If I did not receive fair treatment like my brother, I would be very angry".

On dimension of optimism, subject had an optimistic attitude towards the future. He was sure of his success. He said "I must rise, I must succeed. I educated myself to be independent, not dependent on people. That's why I can do it all myself. The presence or absence of parents should not bury my dreams".

On dimension of problem causal analysis, the subject has the ability to analyze the cause of a problem, that is why he can grow up to be a person who has a hardiness character, without a failed future plan and why he can continue his master degree study. He said "I often hear grandparents getting angry. I was also beaten. Often being told around. So I turned out like this".

Other statement:

"I've also lived with uncle. I was educated with discipline, binding rules. Eventually I slowly changed to be not as dissident and angry as I used to. I can finally control my emotions and be patient. however, I was unable to speak up, because of discipline and fear of talking. If there is a problem I save it for myself and I don't have friends to share".

Other statement :

"I realized why I had failed the police, army and IPDN tests. Because my intention there were never supported nor sanctioned by my grandparents"

Other statement:

"But soon after, I think, I received the grant from LPDP scholarship because I was not destined to work, but I was destined to teach. Because the unaccomplished dream of my parents were to teach. My grandmother also said that, she wanted to teach but was asked to marry a man she did not like. So I think God did not allow me to work because God wants me to realize my mother and grandmother's dream"

On dimension of empathy, The subject has difficulty in expressing his empathy. He tends to avoid affectionate events, because he felt that he never felt affection before. He said "I tend to withdraw from such things. Looking at the familiar friendship of others, I often thought I wanted to go but then I remembered who I was, and I finally step-back. I felt inferior. I felt unequal to them"

On dimension of self-efficacy the subject has the belief that he can be a successful and good person. Although he has been educated harshly by his family, he is convinced that he can change. He said: "I feel like I have to change, because no one wants to help me. That I can push myself. I receive no support from my family at all. After I graduated from high school, I once enlisted to police office, army, IPDN, immigration, aviation, navy, two universities, plus odd jobs in various places I applied. He also said "I am determined in the heart "I'M must change", if you do not change then your life will be the same as your parents".

On dimension of reaching out, there is an increasing positive aspect in the subject where he can view positively every events that occurred in his life. First of the aspect of spirituality, as the subject views religion to play an important role in every part of life. He said .".... I also plan to build a islamic shool. For me education about religion is important". Second, is that everything is arranged by God as well as it can possibly be. He said: I failed those places but I was graduated with LPDP scholarship. Had it not happened I might ended up in a cruise ship". Third, the subject's initiative to engage in social activities when 
IJASOS- International E-Journal of Advances in Social Sciences, Vol. III, Issue 9, December 2017

experiencing loneliness "I believe God has arranged in such a way. He said: I love social activities, so I also work as a volunteer teacher. I am also active in organizations inside and outside campus. By meeting many people there I fill my loneliness"

\section{DISCUSSION}

Children who experienced divorce and parental death requires resilience and seek sources of resilience so that they can continue to live more positively. These sources can be influenced by family, peers, cultural values, religiosity, and social environment. Resilience helps the individual avoid pressuring stress and depression while still being productive (Ruswahyuningsi \& Afiatin, 2013). Low subject resilience is characterized by a sense of inferiority; un-openness and the absence of external support that help subject in building the future well even without the drive to be successful, a condition that happened due to low selfesteem rooted in his family circumstances. This is consistent with research conducted by Lennon \& Heaman (2015) that Individuals with low resilience ability are characterized by low self-esteem, high perceptions of stress, and low interpersonal support that will adversely affect the child's psychological development. In the data that has been obtained on the characteristics of resilient individuals from the subject, it is seen that subject has a negative judgment about himself characterized by a sense of inferiority, closed personality and the absence of external support to push the subject to have a better plan for the future, subject also do not have the desire for success due to low self-esteem because of his family circumstances. This is consistent with research conducted by Lennon \& Heaman (2015) that Individuals with low resilience capability are characterized by low self-esteem, high perceptions of stress, and low interpersonal support that will adversely affect the child's psychological development. Nevertheless, these aspects are not enough to be the main basis for concluding that subject has failed to be resilience when asked about his life. This conclusion was based on further exploration on the subject of the study when conducting in-depth interviews.

Cohesive families enable the children to draw on individual resilient attributes in spite of the ongoing interparental conflict (Pomrenke, 2006). In this particular research, it is noted that, IM did not get full support from his family. When his parents divorced his mother decided to work as a female labor (TKW), his father did not care about his life anymore because he already had a new family and rarely visited the subject. When both parents died IM often get rough upbringing from his grandparents. Whatever IM wants to do, it did not get the support he needed. The subject had experienced the loss of passion to reach his dream and only hoped for bad things for the future. However, with his initiative IM managed to overcome the negative impact of divorce and death of parents with social activities that he followed.

He said :

"I did not have any real plans . I was waiting to die. I did not have ambitious planning to be anything. I did not have anybody else. So I was just happy with myself. I am grateful I can still eat with my own savings. Eating a lot made me already happy. I want to make grandmother happy, but there are other children who can help. I want to make my brother happy, but he has his wife"

"No one wants to help me, there is no support for my future. Finally I myself have to look for a way to my own life"

Lack of family support and a place to share stories made the subject lonely. The sense of loneliness that he faced only occurs at certain moments like in the absence of activity. This can be overcome by subject through positive activities to alleviate his sense of loneliness. Altundag \& Bulut (2014) states that loneliness can affect a person's resilience ability. Known from the interview, when subject feel lonely he took the initiative to engage in social activities, as it can fill the sense of loneliness due to the loss of both parents. Usually, when divorce occurs within the family, close relatives and grandparents provide wide social, financial and emotional support (Altundag \& Bulut, 2014). This plays an important role in reducing loneliness, which is a risk factor for endurance. But this support could not be obtained by the subject of research. Furthermore, in this study this turned into a risk factor that reduces subject's resilience, but the fact is, subject managed to survive the traumatic event that he experienced even though he did not get the support of his close family. This happened because the subject has sources of resilience that is from his involvement with social activities, and it successfully built a view of being an individual who excels and be positive. It appears that there are internal factors within the subject that drove him to become a positive individual.

A person who has the ability to resonate well will be able to develop more positively to focus more on the competencies that exist in him (Linley \& Joseph, 2004). Individuals who are able to adapt to the environment are individuals who are able to accept reality and are able to solve every problem faced with good, confident, open, purposeful and responsible emotional control can also establish relationships in a quality way (Ningrum, 2013). The individual's ability to positively interpret events in his life is a form of deep selfacceptance of himself and his personal situation that includes the past, present, and future (Ruswahyuningsi 
\& Afiatin, 2013). The above components are met on the subject of the study. In the end, the subject accepted sincerely the traumatic events that happened to him. This success is caused by the factors of such as the subject's initiative of engagement in the social activity so that in the end the subject is able to fully accept the traumatic events he experienced. He said: I feel I have to change, because no one wants to help me. only my self can change myself.

The emergence of subject initiative is caused because the subject has intellectual maturity in thinking so that the subject has the knowledge to analyze activities that give good or positive impact on him. Elements of psychological maturity such as cognitive functioning, for example thinking, reasoning, and understanding can be an important thing in adulthood. The individual has a rational understanding of the processes involved in the social activity and avoiding criminal activity. Research proves that engagement into social and cultural activities is associated with higher well-being and resilience (Rapacciuolo et al., 2016). Young adulthood is characterized by the desire to actualize all ideas and thoughts that are matured during high education (university/academy). When entering young adulthood, usually individuals have reached mastery of science and skills mature. Individuals will be able to solve problems systematically and able to develop his creativeinitiative power so that he will gain new experiences, with these experiences, the more mature his mental qualities will be (Hurlock, 1993).

\section{CONCLUSION}

The impact of divorce and death of parents is influential toward the emergence of psychological problems such as loneliness, low self-esteem, difficulty trusting others and lack of nurturing in family. Subject has problems in regulating emotions, impulse control, optimism and empathy, but the sources of resilience that the subject has, especially those from his involvement in social activities can help subject overcome the effects of divorce and parents death and successfully rebuilding the hopes of those who have support him, so that the effect of trauma from death of both parents is decreasing on the subject's independence and in his effort to become a successful person. Subject begins to focus his attention toward the institution that has educated him and to reach his goals in the field of education, which ultimately has a major influence on the dynamics of subject resilience. Young adulthood is characterized by the desire to actualize all ideas and thoughts that are getting matured during high education (university/academy).When entering young adulthood, usually individuals have reached mastery of science and skills maturation. Individuals will be able to solve problems systematically and able to develop his creative-initiative capability so that he will gain new experiences, with these experiences, the more mature his mental qualities will be.

\section{ACKNOWLEDGMENT}

Acknowledgments the researcher conveyed to Indonesian Endowment Fund for Education (LPDP) of Ministry of Finance of the Republic of Indonesia, which has become a major sponsor for researchers to be able to attend this conference. Thanks also to the subject of research who has been willing to share his life experience with the analysis based on Psychology science. Thank you also, the author to convey to Mrs. Tina Afiatin and Mrs. Budi Andayani who has been willing to be mentors for the perfection of this paper.

\section{REFERENCE}

Altundag, Y., \& Bulut, S. (2014). Prediction of Resilience of Adolescents Whose Parents Are Divorced. Psychology, 5(10), 1215-1223. https://doi.org/10.4236/psych.2014.510134

Atwater, E. \& Duffy. K. G. (1999). Psychology for living: Adjusment, growth, and behavior today (6th editon). New Jersey: Prentice - Hall, Inc.

Bandura, A. (1977). Self Efficacy: Toward a Unifying Theory of Behavioral Change. Psychological Review, $84,191-215$

Brown, R. (2015). Building children and young people's resilience: Lessons from psychology. International Journal of Disaster Risk Reduction, 14, 115-124. https://doi.org/10.1016/j.ijdrr.2015.06.007

Bucur, E., Bucur, V. M., \& Runcan, P.-L. (2013). An Analysis of Intervention in Child Protection from the Perspective of the Child's Resilience in Romania. Procedia - Social and Behavioral Sciences, 84, 954-958. https://doi.org/10.1016/j.sbspro.2013.06.681 
IJASOS- International E-Journal of Advances in Social Sciences, Vol. III, Issue 9, December 2017

Connor, K.M., \& Davidson., J. R. T. 2003. Development of a New Resilience Scale : The Connor - Davidson Resiliene Scale (CD-RISC). Deppresion and Anxiety, 18

Creswell, J, W. 2015. Penelitian Kualitatif \& Desain Riset. Yogyakarta : Pustaka Pelajar

Estuti, W. T. (2013). Dampak Perceraian Orang Tua Terhadap Tingkat Kematangan Emosi Anak Kasus Pada 3 Siswa Kelas Viii Smp Negeri 2 Pekuncen Banyumas Tahun Ajaran 2012/2013. Skripsi. Universitas Negeri Semarang.

Gladstone, B. M., Boydell, K. M., \& McKeever, P. (2006). Recasting research into children's experiences of parental mental illness: Beyond risk and resilience. Social Science \& Medicine, 62(10), 2540-2550. https://doi.org/10.1016/j.socscimed.2005.10.038

Grotberg, H. (2000). Resilience for today : Gaining strength from adversity. (Rev. Ed). United States of America : Greenwood Publishing Group, Inc

Hurlock, E, B.(1993) . Psikologi Perkembangan: Suatu pendekatan sepanjang rentang kehidupan (edisi kelima). Jakarta: Erlangga.

Lennon, S. L., \& Heaman, M. (2015). Factors associated with family resilience during pregnancy among inner-city women. Midwifery, 31(10), 957-964. https://doi.org/10.1016/j.midw.2015.05.007

Linley, P. A., \& Joseph, S. (Eds.). (2004). Positive psychology in practice. Hoboken, N.J: Wiley.

Ningrum, P, R. (2013). Perceraian orang tua dan penyesuaian diri remaja. eJournal Psikologi, 1 (1) 69-79, http://ejournal.psikologi.fisipunmul.ac.id/site/wpcontent/uploads/2013/04/JURNAL\%20SKRIPSI\%20PU TRI\%20PDF\%20(04-04-13-09-50-30).pdf

Pandya, S. P. (2017). Spirituality for Building Resilience in Children of Divorced Parents: A Cross-Country Experimental Study. Journal of Divorce \& Remarriage, 58(6), 447-468. https://doi.org/10.1080/10502556.2017.1343554

Poerwandari, E,K. 2005. Pendekatan Kualitatif. Depok : LPSP3 UI

Pomrenke, M. (2006). Resilience in children of high-conflict separated/divorced parents. Thesis. University of Manitoba

Poole, J. C., Dobson, K. S., \& Pusch, D. (2017). Childhood adversity and adult depression: The protective role of psychological resilience. Child Abuse \& Neglect, 64, 89-100. https://doi.org/10.1016/j.chiabu.2016.12.012

Rapacciuolo, A., Perrone Filardi, P., Cuomo, R., Mauriello, V., Quarto, M., Kisslinger, A., ... Tramontano, D. (2016). The Impact of Social and Cultural Engagement and Dieting on Well-Being and Resilience in a Group of Residents in the Metropolitan Area of Naples. Journal of Aging Research, 2016, 1-11. https://doi.org/10.1155/2016/4768420

Reivich, K \& Shatte, A. (2002). The Resilience Factor; 7 Essential Skill for Overcoming Life's Inevitable Obstacle. New York, Broadway Books

Ruswahyuningsi, M. C., \& Afiatin, T. (2013). Resiliensi pada Remaja Jawa. Gadjah Mada Journal of Psychology, 1(2). Retrieved from http://journal.ugm.ac.id/gamajop/article/view/7347

Thomas, D. A., \& Woodside, M. (2011). Resilience in Adult Children of Divorce: A Multiple Case Study. Marriage \& Family Review, 47(4), 213-234. https://doi.org/10.1080/01494929.2011.586300

Yusuf,M, Y. (2014). Dampak perceraian orang tua terhadap anak. Jurnal Al Bayan, 20 (29). Retrieved from http://jurnal.ar-raniry.ac.id/index.php/bayan/article/viewFile/112/101 